\title{
PENGALIHAN KEPEMILIKAN SAHAM SECARA MELAWAN HUKUM DALAM TRANSAKSI REPURCHASE AGREEMENT (REPO)
}

\author{
oleh : \\ Annisa Rahmawati \\ Eni Dasuki Suhardini, S.H., M.H.
}

\begin{abstract}
ABSTRAK
Investasi merupakan salah satu sumber dan modal yang diperlukan dalam mencapai tujuan pembangunan ekonomi suatu negara. Investasi yang dimaksud yaitu di bidang pasar modal, dan salah satu bentuk transaksi yang banyak diminati oleh para pelaku pasar modal adalah transaksi Repurchase Agreement (repo). Repurchase Agreement (repo) adalah transaksi jual beli efek antara dua belah pihak yang didasari dengan adanya suatu perjanjian dimana pada tanggal yang telah ditentukanakan dilaksanakan pembelian kembali atas efek yang sama dengan harga tertentu yang telah disepakati. Permasalahan dalam transaksi repo muncul salah satunya ketika pembeli awal mengalihkan kembali hak kepemilikan atas efek tersebut kepada pihak ketiga (re-repo) sehingga tidak dapat melakukan kewajibannya untuk menjual kembali efek tersebut kepada penjual awal dalam jangka waktu yang telah disepakati dan menyebabkan kerugian pada pihak penjual. Permasalahan yang diteliti adalah mengenai mekanisme dan status atas kepemilikan saham yang menjadi objek dalam transaksi repo serta bagaimana akibat dan upaya penyelesaian yang dapat dilakukan jika terjadi peristiwa kegagalan pada saat jatuh tempo pembelian kembali. Berdasarkan analisa data yang dilakukan, diperoleh kesimpulan yang menunjukan bahwa pihak pembeli merupakan pihak yang berkedudukan sebagai pemilik atas saham yang menjadi objek dalam transaksi repo dan dapat mengalihkan atau menjual kembali saham kepada pihak ketiga dengan tetap terikat pada syarat janji untuk menjual kembali saham tersebut kepada pihak penjual serta harus ada itikad baik berupa pemberitahuan atau persetujuan dari pihak penjual selaku pemilik awal. Pengalihan hak atas kepemilikan saham dari penjual kepada pembeli dalam transaksi repo sifatnya hanya sementara, artinya saham tersebut tidak dijual secara lepas sebagaimana perjanjian jual beli pada umumnya dikarenakan adanya klausula hak membeli kembali. Apabila ada pihak yang merasa telah dirugikan dalam transaksi repo dapat mengajukan upaya penyelesaian melalui jalur litigasi ke peradilan umum dengan klaim gugatan perbuatan melawan hukum atau wanprestasi, dan/atau melalui jalur non-litigasi yaitu ke Badan Arbitrase Pasar Modal Indonesia (BAPMI). Forum penyelesaian sengketa disesuai dengan klausul yang terdapat dalam perjanjian yang telah disepakati para pihak. Adapun saran yang dapat diberikan adalah perlu adanya ketentuan pengamanan terhadap efek yang menjadi objek transaksi repo selama jangka waktu transaksi repo belum selesai dan perlu adanya penegasan dalam penentuan klausula forum penyelesaian sengketa sehingga di kemudian hari tidak ada kerancuan dalam pelaksanaannya.
\end{abstract}

Kata Kunci : Investasi, Pasar Modal, Saham, dan Repurchase Agreement (repo).

\section{PENDAHULUAN}

\section{A. Latar Belakang Masalah}

Indonesia merupakan sebuah negara kepulauan yang terdiri dari gugusan pulau-pulau besar dan kecil, dimana secara geografis Indonesia terletak di antara dua benua yaitu benua Asia dan Australia serta dua samudera yaitu samudera Hindia dan Pasifik. Keadaan geografis ini menjadikan Indonesia sebagai salah satu negara yang berada di persimpangan 
lalu lintas perdagangan dunia. Posisi ini sangat strategis dan penting dalam kaitannya dengan tujuan pembangunan ekonomi suatu negara. Namun dalam kenyataannya hal ini tidak menjamin kemudahan bagi Indonesia dalam mencapai target pembangunan ekonomi nasional. Diperlukan adanya pengembangan terhadap dunia usaha yang merupakan salah satu penentu tercapainya target tersebut. Negara wajib untuk memberikan pengarahan dan bimbingan dalam rangka pengembangan dunia usaha dan terciptanya iklim usaha yang baik. Bimbingan dan pengarahan tersebut akan mendorong kearah pertumbuhan ekonomi yang merupakan kenyataan bahwa investasi dalam jumlah besar dan berkelanjutan sangat diperlukan untuk pembiayaan pembangunan suatu negara.

Investasi merupakan salah satu sumber dan modal yang diperlukan dalam mencapai tujuan pembangunan ekonomi. Investasi yang dimaksudkan di sini adalah investasi di pasar modal. Tipe investasi yang bisa dipilih oleh seorang pebisnis atau mereka yang memiliki kelebihan dana adalah dengan investasi baik secara langsung (direct investment) atau investasi secara tidak langsung (indirect investment) di pasar modal. ${ }^{1}$ Investasi sebagai salah satu sumber pembiayaan pembangunan dan merupakan agenda prioritas dalam Rencana Pembangunan Jangka Menengah Nasional (selanjutnya disebut RPJMN) merupakan modal yang diperlukan di dalam pembangunan ekonomi untuk mencapai tujuan pembangunan nasional. Salah satu investasi yang dimaksud di dalam RPJMN adalah investasi di pasar modal.

Pasar modal bertujuan menunjang pelaksanaan pembangunan nasional dalam rangka meningkatkan pemerataan, pertumbuhan, dan stabilitas ekonomi nasional ke arah peningkatan kesejahteraan untuk rakyat. $^{2}$ Pasar modal sebagai salah satu penunjang pelaksanaan pembangunan nasional harus dapat mengantisipasi berbagai perubahan dan perkembangan yang terjadi dalam rangka melaksanakan fungsinya. Menurut Mochtar Kusumaatmadja bahwa peranan hukum dalam pembangunan adalah untuk menjamin bahwa perubahan di dalam masyarakat tersebut terjadi dengan cara yang teratur. Perubahan maupun ketertiban merupakan tujuan kembar dari masyarakat yang sedang membangun, hukum menjadi suatu alat yang tidak dapat diabaikan dalam proses pembangunan. ${ }^{3}$

Pelaksanaan pembangunan ekonomi suatu negara tentu diperlukan adanya pembiayaan baik dari pihak pemerintah maupun masyarakat. Indonesia sejak akhir tahun 1960-an berkonsentrasi pada pembangunan secara sistematis dengan mengupayakan penghimpunan dana untuk sektor pembangunan, potensi dana masyarakat Indonesia harus bisa dioptimalkan untuk digunakan. Untuk itu dibentuklah pasar modal yang dimaksudkan sebagai wahana untuk memenuhi kebutuhan pembiayaan pembangunan tersebut. Dalam perjalanannya, pasar modal Indonesia sempat dibekukan karena Perang Dunia I dan II dan adanya kebijakan nasionalisasi, hingga akhirnya untuk memenuhi pembiayaan tersebut Indonesia mengaktifkan kembali kegiatan bidang pasar modalnya. Dengan pengaktifan kembali pasar modal diharapkan mampu menggerakkan potensi masyarakat untuk berpartisipasi dalam pembangunan sekaligus menciptakan pemerataan pendapatan dan demokratisasi ekonomi serta dimaksudkan untuk mempercepat proses pengikutsertaan

1- Irham Fahmi, Pengantar Pasar Modal, Alfabeta, Bandung, 2012, hlm. 4.

2- Lastuti Abubakar, Transaksi Derivatif di Indonesia-Tinjauan Hukum Tentang Perdagangan Derivatif di Bursa Efek, Books Terrace \& Library, Bandung, 2009, hlm. 3.

${ }^{3-}$ Mochtar Kusumaatmadja, Konsep-konsep Hukum dalam Pembangunan-Kumpulan Karya Tulis, Alumni, Bandung, 2014, hlm. 20. 
masyarakat dalam pemilikan saham perusahaan-perusahaan sehingga dapat dipergunakan secara produktif. ${ }^{4}$

Pasar modal merupakan salah satu sarana investasi yang tepat baik bagi pemerintah atau swasta, dimana keberadaan pasar modal ini mempermudah pengusaha dan perusahaan yang kekurangan dana untuk dapat menghimpun dana. Pasar modal memiliki peranan yang penting dalam perekonomian suatu negara. Pasar modal dapat memberi alternatif untuk peningkatan permodalan dalam bentuk dan cara penerbitan saham di perusahaan. Masyarakat dapat membeli saham-saham yang ditawarkan atau tercatat dan diperdagangkan di pasar modal. Selain manfaatnya untuk perusahaan, pasar modal juga bermanfaat bagi masyarakat dalam pengalokasian dana secara efisien dan efektif. Pasar modal sama seperti jenis pasar lainnya yang kita kenal yaitu tempat untuk mempertemukan penjual dan pembeli. Yang membedakan pasar modal dengan jenis pasar lainnya yaitu tentu adalah objek yang diperjualbelikan, pada pasar lainnya objek yang diperjualbelikan berupa barang-barang yang konsumtif, sedangkan pada pasar modal objek yang diperjualbelikan adalah modal dalam bentuk efek (surat berharga) salah satunya berupa saham-saham.

Pihak yang menyelenggarakan dan menyediakan sistem perdagangan efek dan sarana untuk mempertemukan penawaran jual beli efek pihak lain dengan tujuan memperdagangkan efek di antara mereka adalah PT. Bursa Efek Indonesia yang didirikan secara khusus untuk mengelola Bursa Efek Indonesia (selanjutnya disebut BEI). ${ }^{5}$ Secara umum efek yang biasanya diterbitkan dan diperdagangkan di BEI diklasifikasikan ke dalam dua jenis yaitu ekuitas dan efek utang. Efek ekuitas yang umum dikenal masyarakat adalah saham dan turunannya, sedangkan efek utang yaitu obligasi.

Salah satu bentuk transaksi yang cukup banyak diminati oleh pelaku pasar modal saat ini adalah transaksi Repurchase Agreement (selanjutnya disebut Repo) saham. Transaksi repo ini pada dasarnya merupakan perjanjian di pasar modal yang timbul dari perkembangan perjanjian yang dilandasi dengan asas kebebasan berkontrak, sebagaimana diatur di dalam Pasal 1338 KUH Perdata. Di Indonesia, perkembangan transaksi repo mengalami peningkatan yang cukup signifikan. Perkembangan tersebut ditandai dengan meningkatnya total volume tahunan tertinggi pada periode 2011-2015 yang mencapai nilai tertinggi yakni 150,2 triliun dengan nilai transaksi senilai Rp. 136,8 triliun. Peningkatan tersebut diiringi dengan munculnya berbagai permasalahan seiring semakin dikenalnya transaksi repo tersebut, sehingga akan menimbulkan suatu ketidakpastian hukum. Pada saat itu, muncul berbagai permasalahan yang dikarenakan belum adanya suatu regulasi yang khusus mengatur tentang pelaksanaan dari transaksi repo.

Untuk mengatasi permasalahan tersebut, pada tahun 2015 dibuatlah ketentuan mengenai transaksi repo oleh Otoritas Jasa Keuangan (selanjutnya disebut OJK) dengan mengeluarkan Peraturan Otoritas Jasa Keuangan Nomor 9/POJK.04/2015 tentang Pedoman Transaksi Repurchase Agreement bagi Lembaga Jasa Keuangan (selanjutnya disebut POJK repo) yang diberlakukan secara efektif mulai 1 Januari 2016. POJK tersebut diterbitkan dengan maksud untuk memberikan pedoman standar transaksi repo yang mengacu pada praktik yang berlaku secara internasional serta memberikan kepastian hukum bagi lembaga jasa keuangan yang melakukan transaksi repo. Pasal 1 ayat (1) POJK repo menyebutkan bahwa :

4) Nasarudin, (et all)., Aspek Hukum Pasar Modal Indonesia, Edisi Pertama, Cetakan Ketujuh, Kencana Prenada Media Group, Jakarta, 2011, hlm. 2.

5- Ibid, hlm. 124. 
"Transaksi repurchase agreement yang selanjutnya disebut transaksi repo adalah kontrak jual beli efek dengan janji beli atau jual kembali pada waktu dan harga yang telah ditetapkan."

Transaksi repo wajib mengakibatkan adanya suatu perubahan kepemilikan atas efek. Kepemilikan efek-efek dalam transaksi repo wajib beralih dari penjual kepada pembeli melalui transaksi yang sah di bursa efek. Ketentuan pengalihan kepemilikan ini diatur dalam Pasal 3 ayat (1) POJK repo yang menyebutkan bahwa setiap transaksi repo wajib mengakibatkan perubahan kepemilikan atas efek. Perubahan kepemilikan efek terjadi pada saat penyerahan efek dan uang pembelian efek tersebut. Penyerahan menyebabkan hak milik atas benda tersebut beralih menjadi milik dari si pembeli. Pembeli yang memiliki hak milik mempunyai kekuasaan penuh atas benda tersebut termasuk untuk mengalihkan atau menjaminkannya tanpa perlu persetujuan dari pihak lain.

Meningkatnya transaksi repo di pasar modal serta tingginya potensi transaksi ini juga telah mengakibatkan timbulnya berbagai permasalahan dari mulai pelanggaran kewajiban pelaporan, harga saham yang turun drastis, gagal bayar, wanprestasi, sampai dengan adanya transaksi repo yang fiktif. Biasanya, pihak pertama yang menerima saham merepokan kembali (re-repo) saham yang dipegangnya kepada pihak lain (pihak ketiga). Padahal, ia memiliki kewajiban untuk mengembalikan saham tersebut kepada pemilik saham dalam kurun waktu tertentu. Tindakan merepokan kembali atau menjual saham kepada investor membuat pemilik saham kesulitan dalam memperoleh sahamnya kembali, sedangkan investor lain yang membeli saham tersebut pun banyak yang tidak mengetahui bahwa saham yang akan atau telah dibelinya tersebut telah direpokan oleh pemilik pertama.

Transaksi repo dalam praktiknya masih ditemukan kasus dimana salah satu pihak melakukan suatu tindakan yang tidak sesuai dengan perjanjian, sehingga mengakibatkan adanya kerugian bagi pihak lainnya. Dengan kata lain meskipun OJK telah menerbitkan dan memberlakukan POJK repo, dalam praktik masih ditemukan perbuatan yang merugikan dan tidak sesuai dengan peraturan. Hal tersebut sebagaimana yang terjadi dalam kasus transaksi repo saham PT. Hanson Internasional Tbk antara Benny Tjokro dan Platinum Partners Value Arbitrage Fund. Dalam hal pihak pembeli atau perusahaan efek sebagai agen penjual dalam transaksi saham di atas lalai tidak melaksanakan kewajibannya sehingga terdapat kerugian yang dirasakan oleh penjual, maka pihak yang bersangkutan harus bertanggung jawab.

\section{B.Identifikasi Masalah}

Berdasarkan latar belakang yang telah diuraikan di atas, maka penulis dapat mengidentifikasikan masalah sebagai berikut :

1. Bagaimana status dan mekanisme atas pengalihan kepemilikan saham yang dijadikan sebagai objek dalam transaksi repurchase agreement (repo) di Bursa Efek Indonesia?

2. Bagaimana akibat dan upaya penyelesaian yang dapat ditempuh sehubungan dengan adanya pengalihan kepemilikan saham secara melawan hukum dalam transaksi repurchase agreement (repo)?

\section{TINJAUAN PUSTAKA}

Pasal 33 ayat (4) Undang-Undang Dasar 1945 amandemen keempat (selanjutnya disebut UUD 1945) menyebutkan bahwa perekonomian nasional diselenggarakan berdasarkan atas demokrasi ekonomi dengan prinsip kebersamaan, efisiensi berkeadilan, berkelanjutan, berwawasan lingkungan, kemandirian, serta dengan menjaga keseimbangan kemajuan dan 
kesatuan ekonomi nasional. Pasal 33 ayat (4) UUD tersebut mengisyaratkan agar pembangunan ekonomi dibangun atas dasar kemandirian untuk mencapai tujuan yang dikehendaki termasuk didalamnya kemandirian yang berkaitan dengan sumber pembiayaan pembangunan. ${ }^{6}$

Berkembangnya industri pasar modal Indonesia tentu dapat menjadi salah satu alternatif yang penting sebagai sumber pembiayaan jangka panjang bagi beberapa perusahaan di tengah terbatasnya pembiayaan dari sektor perbankan. Pasar modal menyediakan sarana untuk berinvestasi dalam bentuk investasi finansial (financial investment) melalui produkproduk yang lazimnya kita kenal dengan sebutan efek atau sekuritas. Efek yang diperdagangkan di pasar modal dapat berupa penyertaan yaitu saham, berupa hutang yaitu obligasi, dan turunan dari saham atau obligasi yang dimaksud.

Ketentuan umum tentang perjanjian dapat dijumpai pada Pasal 1313 KUH Perdata yang menyebutkan bahwa suatu perjanjian adalah suatu perbuatan dengan mana satu orang atau lebih mengikatkan dirinya terhadap satu orang lain atau lebih. Ketentuan pasal tersebut menimbulkan apa yang disebut dengan "akibat perjanjian-perjanjian", Pasal 1338 ayat (1) KUH Perdata menyebutkan bahwa setiap orang dapat membuat perjanjian dengan bentuk atau isi apapun asal tidak bertentangan dengan undang-undang, kesusilaan, dan ketertiban serta dibatasi dengan ketentuan syarat sahnya perjanjian yang terdapat di dalam Pasal 1320 KUH Perdata. Suatu perjanjian baru akan berlaku, dalam arti akibat-akibatnya diatur oleh hukum dan mengikat para pihak apabila perjanjian tersebut memenuhi syarat sahnya perjanjian. Setiap orang dapat membuat perjanjian, baik perjanjian bernama (nominat) yang diatur di dalam KUH Perdata maupun pejanjian tidak bernama (innominat) yaitu yang tidak diatur di dalam KUH Perdata asalkan tunduk pada syarat sahnya perjanjian. Implementasi asas kebebasan berkontrak pada Pasal 1338 ayat (1) KUH Perdata tersebut harus dibarengi dengan adanya itikad baik, sebagaimana bunyi Pasal 1338 ayat (3). Ayat (3) ini merupakan sandaran asas itikad baik, yaitu bahwa setiap perjanjian harus dilaksanakan dengan itikad baik.

Berdasarkan Pasal 1 angka 1 Peraturan Otoritas Jasa Keuangan Nomor 9/POJK.04/2015 tentang Pedoman Transaksi Repurchase Agreement bagi Lembaga Jasa Keuangan menyebutkan repurchase agreement (repo) adalah kontrak jual atau beli efek dengan janji beli atau jual kembali pada waktu dan harga yang telah ditetapkan. Pada waktu transaksi pertama, pihak penjual menyerahkan efek kepada pihak pembeli yang diikuti penyerahan dana dari pihak pembeli kepada pihak penjual. Pada saat tanggal jatuh tempo pembelian kembali, pihak pembeli akan menyerahkan efek yang sama kepada pihak penjual yang diikuti penyerahan dana dengan jumlah tertentu sebagaimana yang diperjanjikan dari pihak penjual kepada pihak pembeli. Berdasarkan hal tersebut maka hubungan hukum antara para pihak dalam transaksi repo merupakan hubungan kontraktual yang didasarkan atas suatu kontrak. Hukum kontrak mengenal adanya asas personalitas, disimpulkan dari Pasal $1315 \mathrm{KUH}$ Perdata yang berbunyi pada umumnya tiada seorang pun dapat mengikatkan diri atas nama sendiri atau meminta ditetapkannya suatu janji melainkan untuk dirinya sendiri.

Perikatan hukum yang dilahirkan oleh suatu perjanjian hanya mengikat orang-orang yang membuat perjanjian itu dan tidak mengikat orang lain. Sebuah perjanjian hanya meletakkan hak-hak dan kewajiban-kewajiban antara para pihak yang membuatnya. Orang lain atau pihak lain tidak mempunyai sangkut paut dengan perjanjian tersebut. ${ }^{7}$ Akan tetapi

${ }^{6-}$ Lastuti Abubakar, op.cit., hlm. 1.

7- Arus Akbar Silondae dan Wirawan B. Ilyas, Pokok-pokok Hukum Bisnis, Salemba Empat, Jakarta, 2012, hlm. 23. 
Pasal 1317 ayat (1) KUH Perdata memberikan pengecualian terhadap asas personalitas yang berbunyi :

"Dapat pula perjanjian diadakan untuk kepentingan pihak ketiga bila suatu perjanjian yang dibuat untuk diri sendiri atau suatu pemberian kepada orang lain, mengandung suatu syarat semacam itu".

Pasal ini mengkontruksikan seseorang bisa mengadakan suatu perjanjian untuk kepentingan pihak ketiga dengan suatu syarat yang ditentukan atau yang disebut derdenbeding. ${ }^{8}$ Sebagaimana telah diuraikan di awal, bahwa transaksi repo secara umum adalah suatu kontrak jual beli. Kontrak jual beli merupakan jenis kontrak yang paling banyak digeluti anggota masyarakat saat ini. Ketentuan umum tentang perjanjian jual beli merujuk pada Pasal 1457 KUH Perdata yang menegaskan bahwa :

"Perjanjian jual beli adalah suatu perjanjian dengan mana satu pihak mengikatkan diri untuk menyerahkan benda, sedang pihak lain mengikatkan diri untuk menyerahkan sejumlah harga yang disepakati”.

Menurut Subekti, yang dimaksud dengan jual beli adalah suatu perjanjian bertimbal balik dalam mana pihak yang satu (si penjual) berjanji untuk menyerahkan hak milik atas suatu barang, sedang pihak yang lainnya (si pembeli) berjanji untuk membayar harga yang terdiri atas sejumlah uang sebagai imbalan dari perolehan hak milik tersebut. ${ }^{9}$ Sepakat yang dibangun para kontraktan dalam jual beli pada pokoknya berintikan pada sesuatu benda tertentu dengan sejumlah harga yang pasti. Ini pertanda bahwa unsur esensialia perjanjian jual beli adalah benda dan harga. Unsur esensialia adalah unsur yang secara mutlak harus ada dalam suatu hubungan hukum yang bersangkutan, tanpa itu jelas akan kehilangan karakter pokoknya yang membawa akibat lanjut kehilangan jati dirinya. Selain unsur esensialia, dalam perjanjian memiliki unsur naturalia dan aksidentalia sebagai pelengkapnya. ${ }^{10}$ Ketentuan dalam KUH Perdata menghendaki pihak dalam perjanjian jual beli dapat memperjanjikan bahwa penjual berhak membeli kembali benda yang telah dijualnya. Pembelian kembali itu dilakukan dengan mengembalikan harga pembelian ditambah dengan semua biaya-biaya yang telah dikeluarkan oleh pembeli.

Transaksi repo adalah kontrak jual beli efek, sehingga objeknya adalah efek. Efek sebagaimana dijelaskan di muka dapat diklasifikasikan kedalam dua jenis, yakni efek ekuitas dan utang. Contoh efek ekuitas adalah saham. Saham dapat diartikan sebagai tanda bukti penyertaan kepemilikan modal atau dana pada suatu perusahaan. ${ }^{11}$ Jual beli saham dari pemegang saham lama kepada pemegang saham baru tidak dengan sendirinya mengalihkan hak milik atas saham yang menjadi objek jual beli kepada pembeli atau pemegang saham baru. ${ }^{12}$ Hal tersebut mengingatkan pada teori dalam Perseroan Terbatas (PT), pengalihan hak atas saham harus dilakukan dengan akta pemindahan (cessie). Tetapi berbeda dengan pemindahan hak atas saham pada pasar modal. Dalam transaksi jual beli saham di bursa efek dilakukan dengan pembukuan (entry book settlement) atau cara lain yang ditetapkan oleh Peraturan Pemerintah. ${ }^{13}$ Pasal 12 Undang-Undang Nomor 8 Tahun

\footnotetext{
8- Salim HS, Hukum Kontrak-Teori dan Teknik Penyusunan Kontrak, Sinar Grafika, 2006, hlm. 13.

${ }^{9}$ R. Subekti, Aneka Perjanjian, Citra Aditya Bakti, Bandung, 2014, hlm. 1.

10- Moch. Isnaeni, Perjanjian Jual Beli, Refika Aditama, Bandung, 2016, hlm. 27.

11- Irham Fahmi, op.cit., hlm. 81.

12- Ridwan Khairandy, Hukum Pasar Modal, FH UII Press, Yogyakarta, 2010, hlm. 50.

13- Ibid.
} 
1995 tentang Pasar Modal menyebutkan untuk menciptakan dan menjaga perdagangan yang teratur, wajar, dan efisien bursa harus memiliki bagian yang khusus menangani lebih lengkap masalah pengawasan. Saat ini di Indonesia terdapat dua bursa, yaitu Bursa Efek Jakarta (BEJ) dan Bursa Efek Surabaya (BES). Diharapkan kedua bursa ini mampu menciptakan kondisi yang dapat mendorong perusahaan-perusahaan efek berperan dalam pengembangan bursa, memberikan pelayanan yang sebaik-baiknya, serta menjaring investor untuk melakukan investasi di pasar modal. ${ }^{14}$

\section{PEMBAHASAN}

\section{A. Mekanisme Dan Status Atas Kepemilikan Saham Yang Menjadi Objek Dalam Suatu Transaksi Repo di Bursa Efek Indonesia}

Perdagangan saham di BEI pada umumnya dilakukan oleh investor di pasar negosiasi. Banyak kasus tentang transaksi repo saham yang sebagian besar dilakukan di pasar negosiasi. Pasar negosiasi ini banyak diminati oleh para penjual dikarenakan penjual bisa secara bebas menawarkan harga sahamnya kepada calon pembeli tanpa harus terikat akan standarisasi harga saham seperti pada perdagangan di pasar reguler. Pada pasar negosiasi, transaksi efek dilakukan melalui tawar menawar secara individual tanpa memasukan penawaran jual dan permintaan beli pada JATS. Secara umum proses terjadinya transaksi repo saham dimulai dengan adanya penawaran dari calon penjual kepada calon pembeli. Penawaran tersebut berisi penawaran tentang jumlah dan harga saham, jangka waktu pelaksanaan transaksi, dan harga pembelian kembali saham. Dalam kontrak transaksi repo saham, apabila calon pembeli tidak secara langsung menerima penawaran yang diajukan oleh calon penjual maka pihak calon pembeli dapat mengajukan kontra penawaran atas penawaran yang diajukan oleh penjual, sehingga disanalah terjadi yang dinamakan negosiasi atau tawar menawar antara kedua belah pihak. Setelah tercapainya kesepakatan diantara para pihak yang dihasilkan dari negosiasi maka transaksi repo saham di BEI wajib memuat ketentuan-ketentuan yang kemudian dituangkan ke dalam perjanjian tertulis (Pasal 4 ayat (1) dan (2) POJK Nomor 09/POJK.04/2015).

Agar suatu perjanjian menjadi sah maka para pihak harus sepakat terhadap segala sesuatu yang telah ditentukan dalam perjanjian. Perjanjian transaksi repo yang telah dibuat dan berisi kesepakatan diantara para pihak kemudian harus ditandatangani oleh kedua belah pihak sebagai tanda adanya suatu pernyataan kehendak. Penandatanganan tersebut selain merupakan tanda telah terjadi kata sepakat mengenai isi perjanjian juga telah menimbulkan adanya suatu akibat hukum bahwa kontrak tersebut adalah sah dan mengikat para pihak yang membuatnya, sebagaimana dijelaskan di dalam Pasal 1320 dan 1338 KUH Perdata. Para pihak harus melaksanakan isi kontrak, dimana kontrak transaksi repo berisi hak dan kewajiban yang harus dilaksanakan oleh para pihak sebagaimana telah ditentukan dalam kontrak.

Pelaksanaan kontrak transaksi repo saham di BEI terdapat lembaga penunjang pasar modal yang ikut terlibat dalam pelaksanaan kontrak tersebut. Lembaga yang dimaksud adalah Lembaga Kliring dan Penjamin Efek yang diselenggarakan oleh PT. Kliring dan Penjamin Efek Indonesia (KPEI) dan Lembaga Kustodian Sentral yang dilaksanakan oleh PT. Kustodian Efek Indonesia (KSEI). Kesepakatan hasil dari negosiasi para pihak kemudian selanjutnya wajib diproses melalui sistem otomasi perdagangan efek yang disebut Jakarta Automated Trading System (JATS). Setelah diproses melalui JATS, KPEI kemudian melakukan kliring terhadap transaksi yang dilakukan para pihak. Kliring 
merupakan proses untuk menentukan hak dan kewajiban yang timbul dari transaksi repo saham yang dilakukan oleh para pihak (Keputusan Direksi PT. Kliring Penjamin Efek Indonesia Nomor Kep-012/DIR/KPEI/2016). KPEI kemudian menyerahkan Daftar Hasil Kliring (DHK) dalam bentuk dokumen elektronik yang memuat hak dan kewajiban saham dan/atau dana masing-masing Anggota Kliring (AK) dalam rangka penyelesaian transaksi repo saham yang dilakukannya. Setelah dilakukan kliring oleh KPEI, selanjutnya hak dan kewajiban para pihak diselesaikan di KSEI. KSEI merupakan sebuah lembaga yang memiliki tugas sebagai lembaga penyimpanan dan penyelesaian di pasar modal Indonesia. KSEI memberikan layanan jasa salah satunya yaitu penyelesaian transaksi efek di bursa. KSEI dalam memberikan layanan jasa penyelesaian transaksi efek, menggunakan sistem penyelesaian transaksi secara pemindahbukuan dikenal dengan nama The Central Depository and Book Entry Settlement System (C-BEST). Penyelesaian transaksi repo saham di KSEI hanya dapat dilakukan setelah para pihak dalam transaksi melakukan pelaporan ke dalam sistem yang telah disediakan oleh KSEI. Waktu penyelesaian transaksi ditentukan berdasarkan kesepakatan Anggota Bursa (AB) yaitu AB jual dan AB beli. Apabila AB tidak menetapkan waktu penyelesaian transaksi maka penyelesaian dilakukan paling lambat hari bursa ketiga setelah terjadinya transaksi $(\mathrm{T}+3)$. Selanjutnya akan dilakukan pencatatan dan pemindahan perihal kepemilikan efek oleh Biro Administrasi Efek (BAE) yang memiliki wewenang untuk melakukan pendaftaran kepemilikan efek dalam daftar buku pemegang saham dan melakukan pembagian hak berkaitan dengan efek.

Janji membeli kembali saham yang sama pada waktu dan harga yang telah ditetapkan para pihak dalam transaksi repo saham menunjukkan bahwa tujuan dari adanya perjanjian repo saham itu adalah tidak hanya sebatas pada mengalihkan saham dari penjual kepada pembali, tetapi para pihak juga memiliki tujuan agar saham yang telah dijual oleh penjual pada waktu yang telah ditetapkan dapat dibeli kembali oleh penjual. Sedangkan bagi pihak pembeli selain tujuannya untuk menerima penyerahan saham juga bertujuan agar pihak pembeli pada waktu yang telah ditetapkan dapat menjual kembali saham dan menerima sejumlah uang sesuai yang telah disepakati. Perjanjian transaksi repo saham dikatakan berakhir apabila para pihak telah melaksanakan kewajibannya yaitu pada proses penyelesaian pertama $\left(1^{\text {st }} l e g\right)$ maupun proses penyelesaian kedua $\left(2^{\text {nd }} l e g\right)$ yaitu pada saat jatuh tempo pembelian kembali, ini merupakan bentuk transaksi repo dengan metode sell/buy back repo.

Pasal 3 ayat (1) POJK Repo menyebutkan setiap transaksi repo wajib mengakibatkan perubahan kepemilikan atas efek. Ketentuan Pasal 3 tersebut juga dipertegas dalam GMRA Indonesia yang menegaskan bahwa maksud diadakannya transaksi repo yang didasarkan pada GMRA Indonesia adalah untuk mengalihkan kepemilikan efek secara sah. Namun tidak semua aspek hukum yang berkaitan dengan transaksi repo saham telah diatur secara khusus dalam POJK tersebut. Salah satunya berkaitan dengan status kepemilikan saham yang menjadi objek dalam transaksi repo apabila saham tersebut ternyata dijual kembali (re-repo) oleh pembeli kepada pihak ketiga tanpa sepengetahuan atau persetujuan pihak penjual. Dalam POJK tidak secara spesifik diatur mengenai hal tersebut. Ini menyebabkan perlu ditemukannya ketentuan hukum lain yang dapat diterapkan dalam menjawab persoalan tersebut, sehingga kepastian hukum bagi para pihak dalam transaksi repo saham ini dapat diberikan dan dirasakan secara adil.

Berdasarkan kepada Undang-Undang Nomor 40 Tahun 2007 tentang Perseroan Terbatas (PT), bahwa pemindahan hak atas saham dilakukan dengan akta pemindahan hak yang dibuat dengan akta notaris atau akta dibawah tangan. Ketentuan dalam UUPT tersebut sesuai dengan ketentuan dalam Pasal 613 KUH Perdata yang mengatur tentang penyerahan benda yang termasuk dalam kategori benda-benda bergerak tidak berwujud 
atau surat-surat berharga. Dalam KUH Perdata saham dianggap sebagai benda bergerak tidak berwujud dan berdasarkan pada ketentuan dalam UUPT saham yang diakui hanya saham atas nama saja. Berdasarkan ketentuan Pasal 613 KUH Perdata, pengalihan surat berharga atas nama dilakukan dengan cessie atau akta pemindahan hak yang dapat dibuat dengan akta autentik maupun di bawah tangan. Dalam akta tersebut dinyatakan bahwa hakhak tersebut dialihkan kepada orang lain. Jika saham yang dijadikan sebagai objek perjanjian jual beli merupakan saham yang diperdagangkan di pasar modal maka cara pemindahan hak atas saham tersebut tunduk pada ketentuan dalam peraturan perundangundangan di bidang pasar modal, yaitu dengan menggunakan sistem penyelesaian transaksi secara pemindahbukuan yang dikenal dengan sebutan C-BEST sebagaimana telah dijelaskan dalam mekanisme penyelesian transaksi repo saham di BEI.

Adanya hak membeli kembali menunjukkan bahwa pembeli pada dasarnya memperoleh hak milik atas barang yang dibelinya, tetapi dengan memikul kewajiban untuk sewaktuwaktu dalam jangka waktu hak membeli kembali yang telah diperjanjikan menyerahkan kembali barang tersebut kepada penjual. Penyerahan pada waktu penyelesian transaksi repo saham yang pertama secara pemindahbukuan, maka pihak pembeli memiliki kedudukan sebagai pemilik atas saham tersebut untuk memperoleh segala hak yang semula dimiliki atau berada di pihak penjual. Dalam jual beli dengan hak membeli kembali, karena pembeli memiliki kedudukan sebagai 'pemilik yang sempurna' maka pembeli berhak menjual serta memindahkan barang yang menjadi objek jual beli kepada pihak ketiga. Namun demikian, penjualan atau pemindahan barang kepada pihak ketiga tersebut harus tetap terikat pada syarat hak membeli kembali yang ada pada pihak penjual.

Proses transfer saham PT. Hanson International Tbk dari rekening efek milik penjual (Benny Tjokro) ke rekening efek milik Platinum Partners pada saat penyelesaian transaksi pertama maka sejak saat itu terjadi peralihan hak milik atas saham PT. Hanson International Tbk dari penjual kepada Platinum sebagai pembeli. Dengan demikian, kedudukan Platinum adalah sebagai pemilik sempurna atas saham PT. Hanson Internatinaol Tbk dan mendapatkan segala hak yang sebelumnya melekat atau berada di pihak penjual. Platinum dapat mengalihkan atau menjual saham PT. Hanson International Tbk kepada pihak ketiga, tetapi pihak Platinum tetap terikat dengan janji untuk menjual kembali saham tersebut pada tanggal pembelian kembali yang telah ditetapkan secara bersama-sama dalam kontrak dengan pihak penjual awal dan harus adanya itikad baik dari Platinum jika hendak menjual saham tersebut yaitu adanya pemberitahuan atau persetujuan dari penjual awal yang merupakan pemilik awal dari saham tersebut. Penjual merupakan pemilik saham dan pengalihan yang dilakukan berdasarkan repo adalah tidak dijual secara lepas namun hanya bersifat sementara sesuai dengan perjanjian yang mengikutinya terhadap penjualan saham yang dimaksud. Karena walaupun jual beli saham tersebut bersifat sementara dengan klausula hak membeli kembali, apabila terjadi penjualan saham maka terhadap saham dilakukan perubahan nama pemiliknya, sehingga walaupun terdapat perubahan nama pemilik saham apabila diikuti dengan hak membeli kembali yang mengikuti perjanjian sejatinya saham tersebut tidak dijual secara lepas sebagaimana jual beli barang pada umumnya. Sehingga peralihan saham yang dilakukan Platinum kepada pihak ketiga (Goldman Sachs International) dianggap tidak sah. Begitu juga terhadap transaksi yang dilakukan dalam kasus kedua yaitu dimana Nomura yang menjual atau mengalihkan saham MNCN milik PT. Global Mediacom tanpa seijin dan sepengetahuan pemilik awal telah menyebabkan kerugian bagi pemilik atau penjual awal. Dalam kasus kedua ini sama dengan kasus pertama yang mana perjanjian yang dilakukan hanya bersifat sementara atau yang menjadi objek jual beli tidak dilepas secara utuh karena sewaktu- 
waktu harus diserahkan kembali kepada pemilik awal disertai pembayaran sejumlah uang dan biaya-biaya lainnya.

\section{B.Akibat dan Upaya Penyelesaian Yang Dapat Dilakukan Sehubungan Dengan Adanya Pengalihan Kepemilikan Saham Secara Melawan Hukum Dalam Repurchase Agreement (Repo)}

Transaksi repo berlandaskan kepada perjanjian yang mewajibkan para pihak untuk melakukan kewajibannya masing-masing dengan baik. Pihak yang tidak dapat menjalankan kewajibannya harus melakukan tanggung jawab atas perbuatan yang merugikan pihak lain. Sering kali transaksi repo saham ini dilakukan secara berantai atau di re-repokan. Jika salah satu pihak gagal bayar atau gagal serah maka transaksi repo efeknya akan terjadi secara berantai. Pasal 3 ayat (3) POJK Nomor 9 Tahun 2015 tentang Repurchase Agreement Bagi Lembaga Jasa Keuangan menyebutkan bahwa apabila terjadi peristiwa kegagalan (event of default) dalam transaksi repo, para pihak wajib menyelesaikannya sesuai dengan tata cara penyelesaian peristiwa kegagalan serta hak dan kewajiban yang mengikutinya sebagaimana dimuat dalam perjanjian. Bagi pembeli repo saham yang tidak bisa mengembalikan atau disebut juga dengan 'gagal serah' saham kepada pemilik awal (penjual) maka terdapat suatu kewajiban bagi pihak pembeli untuk melakukan suatu pertanggungjawaban atas kewajibannya tersebut, yaitu terhadap permasalahan seperti ini dilakukan dengan cara ganti rugi atas kehilangan saham tersebut.

Akibat dari adanya gagal serah saham tersebut menimbulkan kerugian bagi pihak penjual karena pada dasarnya transaksi repo ini bertujuan untuk mencegah pembeli menjual kembali saham kepada pihak lain, saham yang sudah dibelinya selama jangka waktu yang sudah diperjanjikan karena apabila penjual ingin membelinya kembali penjual berhak memperoleh kembali saham dari pembeli tersebut. Kerugian lain juga bisa didapatkan ketika penjual ingin membeli kembali saham tersebut karena misal di bursa harga saham sedang dalam posisi yang baik atau sedang meningkat dan tentunya sangat merugikan secara immateril bagi penjual karena seharusnya penjual bisa mendapatkan keuntungan dari adanya momentum kenaikan harga saham di bursa. Kerugian immateril lain juga diderita sehubungan dengan reputasi dan nama baik penjual serta hilangnya kesempatan-kesempatan bisnis akibat adanya penjualan saham tersebut. Selain itu juga dapat mempengaruhi pergerakan saham di bursa yang menyebabkan terjadinya penurunan harga saham dan mempengaruhi iklim perdagangan saham emiten lain di bursa.

Pihak penjual awal pada contoh kasus pertama (Benny Tjokro) tidak pernah memiliki hubungan hukum dengan pihak Goldman Sachs (pembeli kedua/pihak ketiga) tidak ada transaksi jual beli, tidak ada pembayaran, tidak ada transfer dana dan/atau pengalihan dalam bentuk apapun, tidak pernah menandatanagi dan/atau melakukan kesepakatan terkait saham PT. Hanson International Tbk. Sehingga tindakan pihak ketiga yang mengaku-aku sebagai pemilik atas saham-saham PT. Hanson International Tbk milik penjual awal jelasjelas dilakukan secara tanpa hak. Penjualan tanpa hak yang dilakukan oleh pihak pembeli awal sebagaimana pada contoh kasus pertama dan kedua pada bab III tanpa sepengetahuan dan persetujuan pemilik awal jelas di sini merupakan perbuatan melawan hukum. Suatu perbuatan melawan hukum merupakan perbuatan yang karena kesalahan, kelalaian, atau kurang hati-hati membawa suatu kerugian bagi orang lain, sehingga mewajibkan si pelaku untuk mengganti kerugian tersebut.

Transaksi repurchase agreement merupakan salah satu jenis transaksi di bidang pasar modal Indonesia yang kini banyak diminati oleh para pelaku pasar modal. Sepintas aktivitas repo mirip dengan transaksi gadai saham, dimana pemilik saham menggadaikan sahamnya pada harga tertentu dengan penebusan yang ditentukan kemudian oleh para 
pihak. Perbedaannya dalam gadai saham objek yang menjadi gadai saham tidak bisa diperjualbelikan, sedangkan dalam repo yang menjadi objek tetap aktif ditransaksikan, karena sifatnya yang tetap aktif itulah menyebabkan transaksi repo kurun waktunya terkadang sangat singkat (overnight). Disamping semakin banyaknya pelaku pasar modal yang memilih mentransaksikan efek-efeknya melalui repo, juga timbul berbagai masalah diantaranya adanya peristiwa kegagalan. Peristiwa kegagalan dalam repo dikenal dengan adanya gagal bayar dan gagal serah. Untuk menyelesaikan sengketa yang timbul karena adanya peristiwa kegagalan dalam transaksi repo maka didirikanlah sebuah lembaga arbitrase sebagai salah satu sarana di bawah aturan yang dikeluarkan oleh Badan Pengawas Pasar Modal dan Lembaga Keuangan (Bapepam-LK) yang sekarang menjadi dibawah naungan Otoritas Jasa Keuangan (OJK), yaitu Undang-Undang Nomor 8 Tahun 1995 tentang Pasar Modal dan berbagai aturan lainnya. Dengan dukungan dari OJK beberapa perusahaan seperti PT. Bursa Efek Jakarta (BEJ), PT. Bursa Efek Surabaya (BES), PT. Kliring Penjaminan Efek Indonesia (KPEI), dan PT. Kustodian Sentral Efek Indonesia (KSEI) serta 17 (tujuh belas) asosiasi di lingkungan pasar modal Indonesia membuat sebuah kesepakatan bersama untuk mendirikan sebuah lembaga arbitrase yang kemudian di beri nama Badan Arbitrase Pasar Modal Indonesia (BAPMI). BAPMI memberikan jasa penyelesaian sengketa apabila diminta oleh pihak yang bersengketa melalui mekanisme penyelesaian di luar pengadilan (out of court dispute settlement). BAPMI menawarkan 3 (tiga) jenis penyelesaian sengketa di luar pengadilan yang dapat di pilih oleh para pihak yang bersengketa, yaitu pendapat mengikat, mediasi, dan arbitrase.

Proses penyelesaian sengketa melalui BAPMI dilakukan dengan cara menyerahkan kewenangan kepada pihak ketiga yang netral dan independen untuk memeriksa dan mengadili perkara pada tingkat pertama dan terakhir. Keputusan yang dijatuhkan bersifat final dan mengikat bagi para pihak dan tidak dapat diajukan banding. Saat penyelesaian persengketaan yang dapat diajukan kepada BAPMI harus memenuhi 4 (empat) unsur yaitu : a. Hanyalah persengkataan perdata yang timbul di antara para pihak sehubungan dengan kegiatan di bidang pasar modal;

b. Terdapat kesepakatan di antara para pihak yang bersengketa bahwa persengketaan akan diselesaikan melalui arbitrase di BAPMI;

C. Terdapat permohonan tertulis dari salah satu pihak yang bersengketa kepada BAPMI; dan

d. Persengketaan bukan merupakan perkara pidana dan administrasi seperti manipulasi pasar, insider trading, dan pembekuan/pencabutan izin usaha.

Syarat terpenting untuk mengajukan permohonan penyelesaian sengketa kepada BAPMI adalah adanya terlebih dahulu suatu perjanjian arbitrase antara para pihak yang bersengketa. Perjanjian arbitrase dituangkan ke dalam bentuk salah satu pasal di dalam perjanjian yang dibuat oleh para pihak sebelum timbul sengketa (klausul arbitrase) atau perjanjian tersendiri yang dibuat para pihak setelah timbul sengketa. Para pihak yang telah terikat dengan perjanjian arbitrase tidak mempunyai hak untuk mengajukan penyelesaian sengketa ke Pengadilan Negeri dan dalam hal ini Pengadilan Negeri tidak berwenang untuk mengadili sengketa para pihak yang telah terikat perjanjian arbitrase.

Jika para pihak tidak mencantumkan klausula arbitrase dalam perjanjian repo yang dibuatnya maka ketika terjadi suatu sengketa para pihak dapat mengajukan permohonan penyelesaiannya melalui jalur lain atau yang disebut dengan jalur litigasi yaitu pengajuan permohonan penyelesaian sengketa ke pengadilan umum, dan terdapat upaya hukum yang dapat ditempuh oleh pihak yang kalah atau merasa bahwa putusan hakim tidak memberikan rasa keadilan baginya yaitu ada upaya hukum biasa dan upaya hukum 
istimewa. Upaya hukum biasa diantaranya adalah verstek (Pasal 128 ayat (1) HIR jo Pasal 152 ayat (1) RBg), banding ke Pengadilan Tinggi, dan kasasi yang diajukan ke Mahkamah Agung serta terdapat upaya hukum istimewa atau luar biasa yaitu peninjauan kembali yang diajukan juga ke Mahkamah Agung.

Jika pihak pembeli dalam transaksi repo masih tidak dapat memenuhi kewajibannya untuk menyerahkan sejumlah saham yang sama yaitu milik penjual maka dapat dikenakan sanksi keperdataan. Setiap pelanggaran yang menyebabkan kerugian bagi orang lain dalam hubungannya dengan pasar modal atau bukan, dapat menyebabkan adanya gugatan perdata bagi pihak yang merasa dirugikan terhadap pihak yang merugikannya. Khusus atas perbuatan hukum yang berhubungan dengan pasar modal, kemungkinan gugatan perdata dapat timbul berdasarkan kepada beberapa alasan yuridis yaitu sebagai berikut :

a. Klaim berdasarkan adanya peraturan perundang-undangan di pasar modal;

b. Klaim berdasarkan atas perbuatan melawan hukum vide Pasal 1365 KUH Perdata;

c. Klaim berdasarkan atas tindakan wanprestasi atas suatu perjanjian.

Pada dasarnya sengketa pasar modal dibagi menjadi 2 (dua) berdasarkan golongan hukumnya yaitu berdasarkan hukum publik dan hukum privat. Pelanggaran-pelanggaran atau permasalahan pasar modal dalam hukum publik yaitu di bidang hukum pidana dan administrasi, sedangkan pelanggaran atau permasalahan di bidang hukum privat yaitu menyangkut keperdataan, contohnya yang lebih sering terjadi adalah permasalahan dalam perjanjian antara satu pihak dengan pihak lain. Penyelesaian sengketa pasar modal di bidang hukum publik dilakukan oleh OJK sebagai lembaga pengawas terhadap berjalannya kegiatan di pasar modal. OJK memiliki kewenangan untuk langsung melakukan penyelidikan terhadap pengaduan adanya pelanggaran di bidang hukum pidana dan administrasi. Sanksi administrasi yang akan diberikan berupa memasukan pihak yang terbukti bersalah ke dalam daftar hitam (black list) yang berdampak pihak tersebut tidak dapat melakukan lagi aktivitas di pasar modal Indonesia. Sedangkan dalam hal terjadinya sengketa pasar modal di bidang hukum perdata, khususnya berkaitan dengan perjanjian para pelaku pasar modal di dalam penyelesaiannya perlu dilihat terlebih dahulu klausul mengenai pemilihan forum penyelesaian sengketa tersebut.

\section{PENUTUP}

\section{Kesimpulan}

1. Transaksi repo merupakan kontrak jual atau beli efek dengan janji beli atau jual kembali pada waktu dan harga yang telah ditetapkan. Efek yang sering diperdagangkan dalam transaksi repo yaitu saham dan saham yang diakui dalam Bursa Efek Indonesia adalah saham atas nama. Setiap transaksi repo sebagaimana diatur dalam Pasal 3 POJK repo wajib untuk mengakibatkan perubahan kepemilikan atas efek. Status kepemilikan saham yang dijadikan objek transaksi repo saham pada dasarnya telah beralih kepada pihak pembeli sejak dilakukannya penyerahan pada waktu penyelesaian pertama $\left(1^{\text {st }} l\right.$ leg $)$ yang dilaksanakan pada Kustodian Sentral Efek Indonesia (KSEI) melalui sitem C-BEST. Pembeli sebagai pemilik baru atas saham tidak dapat mengalihkan atau menjual saham tersebut kepada pihak ketiga karena perjanjian yang dilakukan dengan penjual yaitu perjanjian repo hanya bersifat sementara. Artinya saham tersebut tidak di jual secara lepas karena ada klausul hak membeli kembali yang telah disepakati dalam perjanjian. Dalam proses pembeli mengalihkan atau menjual kembali saham kepada pihak ketiga diperlukan adanya persetujuan atau ijin dari pihak penjual sebagai pemilik awal saham. Meskipun setiap hak yang melekat pada saham tersebut telah beralih menjadi milik 
pembeli, pembeli harus mempunyai itikad baik dan tetap melaksanakan prestasinya sesuai dengan waktu dan harga yang telah ditetapkan dalam perjanjian dengan pihak penjual.

2. Jika pembeli awal tidak dapat melaksanakan kewajibannya pada waktu jatuh tempo atau pada waktu penyelesaian kedua ( $2^{\text {nd }}$ leg) maka pihak penjual dapat mengajukan gugatan atau klaim atas dasar perbuatan melawan hukum dan/atau perbuatan wanprestasi serta dapat melakukan upaya penyelesaian melalui lembaga Badan Arbitrase Pasar Modal Indonesia (BAPMI) yang menawarkan 3 (tiga) proses penyelesaian yaitu pendapat mengikat, mediasi, dan arbitrase. Proses penyelesaian melalui BAPMI merupakan penyelesaian di luar pengadilan (non-litigasi) yang memberikan kemudahan, biaya murah, dan proses cepat. Proses penyelesaian pada BAPMI harus berdasarkan adanya klausula arbitrase pada pasal dalam perjanjian repo saham tersebut. Jika tidak ada klausula arbitrase maka para pihak diberikan pilihan sarana penyelesaian lain yaitu melalui jalur litigasi pada peradilan umum. Para pihak yang merasa tidak puas dengan putusan majelis hakim dapat mengajukan perlawanan melalui upaya-upaya hukum yaitu upaya hukum biasa (banding dan kasasi) dan upaya hukum luar biasa/istimewa (peninjauan kembali). Penggunaan klausula pilihan forum penyelesaian sengketa secara prinsip adalah merupakan kebebasan dari para pihak untuk memilih dan menyepakati forum mana yang akan digunakan jika terjadi suatu sengketa. Inilah prinsip kebebasan berkontrak yang dianut oleh sistem hukum perdata Indonesia. Jika para pihak sudah sepakat setiap sengketa akan diselesaikan di pengadilan, maka harus ke pengadilan, dan lembaga lain menjadi tidak berwenang. Demikian juga sebaliknya, jika para pihak sepakat menyelesaikan sengketa di lembaga arbitrase $X$ maka harus ke lembaga arbitrase $\mathrm{X}$ tersebut dan pengadilan atau lembaga arbitrase lain menjadi tidak berwenang.

\section{Saran}

1. Otoritas Jasa Keuangan telah mengeluarkan Peraturan Otoritas Jasa Keuangan (POJK) Nomor 9/POJK.04/2015 tentang Pedoman Transaksi Repurchase Agreement bagi Lembaga Jasa Keuangan, namun sejauh ini di dalam regulasi tersebut belum ada dan perlu ditambahkan ketentuan tentang bentuk dan mekanisme pengamanan terhadap efek yang menjadi objek dalam transaksi repo. Tujuannya adalah untuk mencegah pihak pembeli mengalihkan efek yang menjadi objek transaksi repo kepada pihak ketiga yang dapat mengakibatkan adanya gagal serah pada waktu penyelesaian kedua $\left(2^{\text {nd }} l e g\right)$.

2. Penulisan klausul oleh para pihak terkadang mengatur dua pilihan forum penyelesaian di dalam kontraknya misalnya klausula pilihan menyebutkan "sengketa akan diselesaikan melalui pengadilan atau arbitrase" atau "jika tidak bisa diselesaikan melalui arbitrase akan diajukan ke pengadilan". Hal tersebut menimbulkan kerancuan dalam pelaksanaannya di kemudian hari, sehingga diperlukan kalimat klausul yang efektif, jelas, dan tegas yang hanya mengacu pada satu forum penyelesaian saja, misalkan BAPMI yang memberikan upaya penyelesaian sengketa dengan mudah, biaya murah, dan proses yang cepat. 


\section{DAFTAR PUSTAKA}

\section{Buku :}

Ahmadi Miru dan Sakka Pati, Hukum Perikatan-Penjelasan Makna Pasal 1233 sampai 1456 BW, PT. Raja Grafindo Persada, Jakarta, 2014.

Arus Akbar Silondae dan Wirawan B. Ilyas, Pokok-Pokok Hukum Bisnis, Salemba Empat, Jakarta, 2012.

Budi Untung, Hukum Bisnis Pasar Modal, Andi Offset, Yogyakarta, 2011.

Dadang Sukandar, Membuat Surat Perjanjian, Andi Publisher, Jakarta, 2011.

Irham Fahmi, Pengantar Pasar Modal, Alfabeta, Bandung, 2012.

Lastuti Akbar, Transaksi Derivatif di Indonesia-Tinjauan Hukum Tentang Perdagangan Derivatif di Bursa Efek, Books Terrace \& Library, Bandung. 2009.

Mariam Darus Badrulzaman, dkk., Kompilasi Hukum Perikatan, PT. Citra Aditya Bakti, Bandung, 2001.

Moch. Isnaeni, Perjanjian Jual Beli, PT. Refika Aditama, Bandung, 2016.

Mochtar Kusumaatmatdja, Konsep-Konsep Hukum dalam Pembangunan-Kumpulan Karya Tulis, Alumni, Bandung, 2014.

Munir Fuady, Pasar Modal Modern-Tinjauan Hukum, PT. Citra Aditya Bakti, Bandung, 2001.

Nasarudin, dkk., Aspek Hukum Pasar Modal Indonesia, Kencana Prenada Media Group, Jakarta, 2011.

Nurnaningsih Amriani, Alternatif Penyelesaian Sengketa Perdata di Pengadilan, PT. Raja Grafindo, Jakarta, 2012.

Ridwan Khairandy, Hukum Pasar Modal, FH UII Press, Yogyakarta, 2010.

R. Subekti, Aneka Perjanjian, Cirta Aditya Bakti, Bandung, 2014.

Salim HS, Hukum Kontrak, Teori dan Teknik Penyusunan Kontrak, Sinar Grafika, Jakarta, 2006.

Sarwono, Hukum Acara Perdata, Teori dan Praktik, Sinar Grafika, Jakarta, 2011.

Soerjono Soekanto dan Sri Mamudji, Penelitian Hukum Normatif, Suatu Tinjauan Singkat, Raja Grafindo Persada, Jakarta, 2010.

\section{Peraturan Perundang-undangan :}

Undang-Undang Dasar Negara Republik Indonesia Tahun 1945.

Kitab Undang-Undang Hukum Perdata (KUH Perdata).

Undang-Undang Nomor 8 Tahun 1995 tentang Pasar Modal.

Undang-Undang Nomor 30 Tahun 1999 tentang Alternatif Penyelesaian Sengketa dan Arbitrase.

Undang-Undang Nomor 21 Tahun 2011 tentang Otoritas Jasa Keuangan.

Peraturan Otoritas Jasa Keuangan Nomor 9/PJOK.04/2015 tentang Pedoman Transaksi Repurchase Agreement bagi Lembaga Jasa Keuangan.

Surat Edaran Otoritas Jasa Keuangan Nomor 33/SEOJK.04/2015 tentang Global Master Repurchase Agreement Indonesia. 